\title{
The Matan and Sanad Criticisms in Evaluating the Hadith
}

\author{
Tuan Mohd Sapuan Tuan Ismail ${ }^{1}$, Rohaizan Baru², Ahmad Fauzi Hassan ${ }^{3}$, Ahmad Zahid bin Salleh ${ }^{3} \&$ Mohd \\ Fauzi Mohd Amin ${ }^{4}$ \\ ${ }^{1}$ Kolej Islam Antarabangsa Sultan Ismail Petra (KIAS) Kelantan, Malaysia \\ ${ }^{2}$ Faculty of Islamic Contemporary Studies/ Research Institute for Islamic Products and Civilization, Universiti \\ Sultan Zainal Abidin, Kuala Terengganu, Malaysia \\ ${ }^{3}$ Department of al-Quran \& al-Sunnah, Faculty of Islamic Contemporary Studies, Universiti Sultan Zainal \\ Abidin, Kuala Terengganu, Malaysia \\ ${ }^{4}$ Faculty of Quranic \& Sunnah Studies, Universiti Sains Islam Malaysia, Nilai, Negeri Sembilan, Malaysia \\ Correspondence: Tuan Mohd Sapuan Tuan Ismail, Kolej Islam Antarabangsa Sultan Ismail Petra (KIAS) \\ Kelantan, Malaysia. Tel: 60-13-635-3463.E-mail: tasekpauh@yahoo.com
}

Received: August 8, 2014 Accepted: August 21, 2014 Online Published: October 30, 2014

doi:10.5539/ass.v10n21p152 URL: http://dx.doi.org/10.5539/ass.v10n21p152

\begin{abstract}
Knowledge on the classification (mustalah) and sciences (ulum) of the al-Hadith that has long existed is the platform for religious scholars to debate the preservation and safeguarding of the originality and authenticity of the Prophet's SAW hadith. The topic is to determine whether to accept or reject the circumstances surrounding the chain of narrators (sanad) and the text of the hadith (matan). The evaluation of a hadith is made based on the sanad and matan criticisms. What is the relationship between these two aspects and to what degree does the role and significance of these two aspects affect the evaluation of a hadith, notwithstanding the criteria needed by parties that intend to evaluate the hadith? Hence, these are some of the questions that reflect the issues in this article. This brief study on the writings by experts in the field has produced a few latent points that can be summarised as; the criticisms of the sanad and matan had begun since the time of the Prophet's SAW companions although criticisms on the matan took preference and dominance due to the need at that moment in time. In the context of evaluating the hadith, both these aspects need to be jointly criticized and not in a separate context. At times, the hadith might have been authenticated based on the sanad, nevertheless criticism of the matan would still be initiated to ascertain that the text of the hadith is safe from contradictory facts or void of any hidden flaws.
\end{abstract}

Keywords: evaluating the hadith, sanad criticism, matan criticism, hadith scholar

\section{Introduction}

According to al-A'zhomi (1990, p. 10), what is assumed as the current method of criticizing the sanad is actually the outcome or findings of criticisms on sanad by former religious scholars. This is because scholars of the al-Jarh wa al-Ta'dil would not have been able to ascertain the status of a narrator; whether he is accepted or rejected, trustworthy or otherwise, carefully safeguards the hadith or is forgetful and froth with mistakes, unless the scholars have studied the narrated texts of the hadith by comparing the matan of their hadith with the matan of other narrators, including views from the logical aspect. Hence, narrators who adduced the matan of the hadith that is incongruous, contradictory and froth with mistakes would have the hadith rejected. Comparisons between narratives and logical criticisms are matan criticisms, which are a part of the methodology of sanad criticism.

\section{Objectives of the Study}

The article is written with the intention of explaining the close relationship between sanad criticism and matan criticism of the hadith because without the matan criticism, the sanad criticism would be incomplete. In fact, the methodology of sanad criticism creates the realization of the matan criticism.

\section{Evaluating the Hadith, Matan Criticism and Sanad Criticism}

Classification of the hadith (mustolah al-hadith) is actually knowledge concerning the evaluation of the hadith. The classification is initiated in order to determine whether a sanad or matan of a hadith is to be accepted or 
rejected. Based on the definition of mustolah al-hadith, the evaluation of a hadith could mean "a process to understand and determine whether a hadith is accepted or rejected and explain the decision with its justifications". "To explain the decision along with its justifications", means to explain the findings of the process pertaining to whether the hadith is accepted or rejected and giving reasons for the decision in a transparent manner.

To evaluate the hadith does not mean to find fault or dishonour the hadith of the Prophet SAW but rather to ensure that the hadith did actually originate from the Prophet SAW or otherwise. It is only intended to differentiate between an authenticated or unauthenticated hadith.

Hence, based on the definition of evaluating a hadith, matan and sanad criticisms could be similarly defined as, "a process to determine if a matan or sanad of a hadith is accepted or rejected and to explain the decisions and the reasons for the decision".

\subsection{Elements of the Sanad and Matan Criticisms that Determine the Implications of the Hadith}

Religious scholars on the hadith have divided the hadith into two sections, which is hadith that is accepted $(a l-m a q b u l)$ and that is rejected (al-mardud). The hadith that is accepted is authenticated and worthy or good (hasan), whereas the hadith that is rejected is false and weak in character. They had jointly stipulated five conditions when determining the authenticity of a hadith. These five conditions are clear proof that these religious scholars had conducted a proper and in-depth study to evaluate the authenticity of the hadith. These five conditions are:

1- Sanad or the chain of continuous narrators means that each narrator had personally received the hadith from his previous teacher. This condition must exist in every chain of sanad from the beginning to the end.

2- The narrators must possess the characteristics of justice ('adalah), meaning that the narrator in the sanad chain must be a Muslim who is physically matured, of sound mind, not impious (fasigh) and has moral integrity.

3- A narrator who safeguards the hadith well (dhabt), either in its memorization or its writing.

4- There are no contradictions (syaz). Meaning that there is no contradiction between one narrator who is trustworthy (thiqah) and another who is much more trusted (the one who is more trusted because of his personality or due to the number of narrators under him).

5- There is no 'illah. 'Illah means "a hidden element that corrupts the hadith although originally the hadith was free from any corruption".

These five conditions were laid down to avoid matters such as deception and mistakes, either on purpose or otherwise.

Hence, if there is an assumption that the first three conditions are specifically related to the sanad criticisms, while the two other conditions comprise both the sanad and matan criticisms, then there is an error in assumption. This is because the careful safeguarding (dhabt) of a narrator will not be known unless a matan criticism is done on that hadith. This criticism is done by comparing texts narrated by the narrator with another. Thus, the hadith by a trustworthy narrator (thiqah) could then be accepted or otherwise, rejected.

A trustworthy (thiqah) narrator can also be forgetful or prone to mistakes. Therefore, the last two conditions are intended to screen the hadith of trustworthy narrators (thiqah) that contain mistakes either in the sanad or in the matan (Abu al-Lais: 150). These five genuine conditions were based on the findings and observations of the religious scholars based on the bio-data and character of the narrators, comparison of the matan or narrated texts and the logical contents found in the hadith.

\subsection{Objectives of the Sanad and Matan Criticisms}

The aim of criticizing the hadith, either its sanad or matan, is to identify the authenticity of a hadith. The eventual outcome of this criticism is to ascertain if the hadith fulfils the condition on authenticity and enables the differentiation of an acceptable (maqbul) or rejected (mardud) hadith.

\subsection{The Basis of Sanad Criticism}

In the sanad criticism, the hadith scholars had evaluated three main issues, such as:

1- The piousness and dignity of a narrator would attest to the biasness and competence of a narrator. Narrators who do not fulfil the condition of fairness would have the hadith rejected considering there might be some untruthfulness in the narrations.

2- The care shown by the narrator and the prudence in narrating the hadith (dbabt) would attest to the narrator's carefulness, either by him memorizing it or writing in down. Narrators who do not fulfil this 
condition would have the hadith rejected due to the probability of mistakes. To determine the duty of care, the critics of the hadith would have to evaluate the texts presented by the narrator. Thus, only after the matan criticisms have been made will the status of care be determined.

3- To ascertain if the chain of sanad is continuous or otherwise because if the chain has been broken, the hadith is not authenticated and will be rejected since there is a possibility of untruthfulness or mistake when the identity of the narrator in the broken chain is unknown.

Knowledge on these three issues are found in literature related to the history of narrators or also known as ilm rijal al-hadith or 'ilm al-ruwah. Briefly, it could be said that the basis for the sanad criticism is the study to answer these three questions, such as:

i. What is source of the narrator's text?

ii. How did he obtain it?

iii. How credible is the narrator?

When these three issues are studied, two other issues related to sanad, which is the absence of syaz and illah, must also be looked into. Moreover, the study of the two latter issues is deemed more difficult compared to the three former issues.

\subsection{Careful Memorization of the Hadith by the Narrator and Its Relations with Matan Criticisms}

According to Ibn Mahdi (al-Kifayah: 435): "the careful safeguarding by a hadith scholar can be proved when his recitation by memory (hafazan) is no different from similar recitations by other hadith scholars". Imam Syafie (al-Risalah:371), when discussing the conditions of accepting a hadith by a narrator said that, "His narrations must be similar to the narrations of other reciters of the hadith and not a mudallis, who narrates a hadith from a narrator he had met but does not accept absolutely what that narrator proclaims. Neither should he narrate from the Prophet SAW a hadith that contradicts the narrations from a trusted narrator". Ibn Solah was of the opinion that, "to identify a prudent narrator is to compare his narrations with the narrations of other famous thiqah narrators". Thus, if there are vast similarities with negligible differences, then he is considered prudent. Conversely, if there are very noticeable differences with the other famous narrators then his prudence is questionable and the hadith is rejected.

Slight differences do not jeopardise the prudence of a narrator because hadith scholars admit the reality that no one is exempted from forgetting or committing mistakes. Imam Muslim (al-Tamyiz: 170) said that, "Not a single narrator is exempt from forgetting although he has an exceptional memory, is extremely careful in memorising his narrations". This is similar to a narrator who is fair or knowledgeable, which does not make him infallible (maksum) but someone who can be accepted from a religious and personality aspect in an Islamic society.

Based on previous statements from religious scholars, it is clear that matan criticisms are part of the tenets of sanad criticisms. The assertions of a narrator's prudence is made by fellow sanad critics from among the al-jarh wa al-ta'dil religious scholars. Hence, when recognising prudence, one has to compare the narrations, which is a process found in matan criticism.

According to al-A'zhomi (1990, p. 67), developments in comparing narrations of hadith scholars saw numerous comparisons. Among them were comparing narrations from the same narrator but during different periods in time, comparing narrations from students tutored under the same religious teacher (guru), to compare the narrations of a narrator with that of his peers, to compare written narrations with memorized narrations, to compare among various written narrations and lastly, to compare the contents of the narrations with the al-Qur'an. These measures would help the hadith scholars to identify the narrator's level of prudence.

He had quoted from Abdullah bin al-Mubarak as saying, "When you intent to determine the authenticity of a hadith, compare it with others". Ayyub al-Sikhtiyani had said, "If you wish to know your teacher's mistakes; then tutor under another teacher".

\subsection{The Basics of Matan Criticisms}

The basics of matan criticism is the comparing of one narrator's hadith texts with that of another and the comparisons made based on numerous aspects iterated earlier. Thus, by comparing the narrations, the critics are able to recognise the narrator's level of prudence and issues that might exist in the matan that contradicts other facts or inconsistencies that are difficult to detect. The matan would then be compared with matan criticism standards consisting of religious referrals from the Qur'an, hadith or even logical deductions in order to ascertain the accuracy and validity of the matan contained in the hadith. 


\subsection{The Standards for Matan Criticism of the Hadith}

Ibn Qayyim al-Jauziyyah was once asked whether a false hadith could be identified by only through the matan of the hadith and without studying the sanad. His answer was in the form of a book entitled Naqd Al-Manqul, which explained the standards that could be used to identify false hadith with ease. He mentioned 13 standards for matan criticism that could be summarised as follows:

First: $\quad$ Hadith that contradict the al-Qur'an

Second: $\quad$ Hadith that contradict other authenticated hadith

Third: $\quad$ Hadith that contradict the basics of the syarak

Fourth: Hadith that have a severe, aggravated or grievous connotation

Fifth: $\quad$ Hadith that contradict authenticated historical facts

Sixth: $\quad$ Hadith that have illogical connotations

Seventh: Hadith that contradict reality

Eight: $\quad$ Hadith that does that reflect the words of the Prophet SAW

The first three standards can be combined and called the syarak standards because it is based on the al-Qur'an and hadith plus the deductions (istinbat) made from both these sources. The remaining five standards can be combined as logical and realistic standards because it is based on the elements of logic and reality.

\subsection{The Scope of Matan Criticisms}

The scope of matan criticism incorporates all hadith, whether authenticated or not. Hence, when the sanad of a hadith is rejected because of its weakness, there is no need to evaluate the matan. However, the scholars, especially those who write about false hadith, still initiate matan criticisms on hadith that have a weak sanad in order to explain the weakness of the hadith. This criticism is to differentiate hadith with a weak sanad but an authenticated matan and a hadith with a weak sanad and matan content of unscrupulous nature. Even though, sometimes they pre-empt matan criticisms when it is absolutely clear that the matan is superficial. Thus, if the sanad is authentic, matan criticisms must still be initiated before a hadith is coveted with the authentic status.

According to al-Hakim al-Naisaburi (Ma'rifah Ulum al-Hadith: 112): "The 'illah is determined in a hadith when there is no 'illah in the sanad. This is because hadith accruing from a 'weak' narrator is deemed to be daif (weak), hence not considered. The 'illah in the hadith is usually found in hadith from trusted narrators, especially when they rather unintentionally adduce hadith with 'illah".

\subsection{The Position of Sanad and Matan Criticisms in Evaluating the Hadith}

Based on the criteria for an authentic hadith, it is clear that hadith scholars, when evaluating a hadith, do pay attention to both tenets of the hadith, namely the sanad and matan and adhere to the sanad and matan criticisms. This is because the authenticity of the sanad does not guarantee that the criteria for an authentic hadith are fulfilled. The sanad could be authentic because it fulfilled the required conditions but the hadith cannot be authenticated just yet due to contradictions or 'illah discovered hidden from the naked eye.

On the other hand, sometimes the matan of a hadith is authentic based on the facts that support its authenticity, hence it is not assumed authentic because there are 'illah in its sanad. According to Ibn al-Jauzi, "there are hadith with the sanad from narrators who are thiqah but found to be false..". Ibn al-Qayyim (Furusiyyah: 245) also said, "It is known that the authenticity of the sanad is one of the conditions for an authentic hadith, hence it cannot establish the authenticity of a hadith".

\subsection{The Priority of Matan Criticisms in the Practice of Evaluating Hadith by Religious Scholars}

The basis of evaluating the hadith using both the sanad and matan was founded since the time of the Prophet SAW; hence, the matan criticism aspect was practiced even before that. This is because there was no need to evaluate the sanad at that time since the Prophet SAW was still alive and any concern could be addressed to the Prophet SAW himself. After the honourable passing of the Prophet SAW, there was still no need to evaluate the sanad of the hadith because the Prophet's SAW companions (sahabat) were very capable and truthful. According to al-Bara' bin 'Azib, "Not all the hadith narrated to you was from what we heard from the Prophet $S A W$; some we heard ourselves from the Prophet $S A W$ and some were narrated by our friends, hence we were never untruthful". In one of his narrations he said, "In Allah's SWT name, we have never been untruthful and we do not know what the untruth is" (Ibn 'Adi: 157-159).

The era of political turmoil in the Islamic world began during the time of the Othman Caliphate. This situation continued until his murder in $35 \mathrm{H}$. After the demise of Osman r.a, an even greater political turmoil erupted that 
brought about deep divides among the Muslims. This turmoil eventually brought the split in religious beliefs because each group went about seeking authoritative claims to buttress their beliefs.

There was the munafiq (disbelievers) group who took the opportunity during this period of disunity to destroy Islam from within and with this emerged Abdullah bin Saba' $(40 \mathrm{H})$ and his followers. He was a Jew from Yamen who became a Muslim during the time of the Osman Caliphate. He was responsible for the political turmoil that eventually took the life of Caliph Osman r.a. and brought about the disunity among Muslims. After Ali r.a was appointed the Caliph, he worshipped Caliph Ali r.a. as God. His followers were called al-Sabaiyyah and they were burnt alive by Ali r.a. and he too was burnt along with them (al-Zarkali, 4:88, al-Zahabi, 3:289).

Political and religious turmoil became worse when al-Mukhtar bin Abi Ubaid al-Thaqafi came into the scene in $67 \mathrm{H}$. The trouble caused by him started around $65-67 \mathrm{H}$. His revenge for the death of al-Hussein bin Ali was his agenda for disrupting political unity. Among his teachings were that Gabriel (Jibril) came to him as a divine revelation (wahyu). Imam Nawawi said that consensus by religious scholars assumed that he was the liar referred to by the Prophet SAW in the hadith narrated by Asma' binti Abu Bakar that within the Thaqif tribe there would be one who lies and murders extensively (al-Nawawi, 16: 100). According to Umar Falatah (1981, 1: 212-213) he was the first person found to pay narrators to falsify the hadith for his political interests.

In addition, many of the Prophet's SAW companions had passed on and the religious atmosphere among the people was not the same as during the times of the companions. This situation had warranted the need to evaluate the narrators of the hadith. According to Ibn Sirin, "Basically, the companions and their followers never questioned the sanad but after the political turmoil they would enquire: Say who was your narrator". Hence, if the narrator was among the members of the Sunnah, then the hadith was accepted and if the narrator was among the propagators of bid'ah (innovations that displeases Allah SWT), then the hadith was rejected" (Sahih Muslim, 1:34)

Questions on the sanad did not occur at once but in stages until the middle of the second century Hijrah when it became a necessity, whereby hadith that were not accompanied by the sanad were rejected (al-Jawabi: 112).

Referring to the matan criticism, it was obviously practiced earlier than the sanad criticisms, back during the time of the noble companions. It was practised by Abu Bakar r.a., who requested a narrator to prove that a grandmother would inherit $1 / 6$ of the grandchild's property, because according to Abu Bakar r.a. there was no religious reference in the Qur'an or hadith on this matter. So too did Umar r.a, who requested Abu Said al-Khudri to prove that the matan of a hadith related to seeking permission from Umar r.a. had truly come from the Prophet SAW. One that clearly proves the occurrence of matan criticism was the matan criticism by Aisyah r.a., as quoted by al-Zarkasyi.

Hence, some examples of hadith scholars evaluating a hadith were quoted earlier and they always prioritized the matan criticisms. According to al-Muhammadi (2005, p. 25), when a sanad of a hadith is brought before religious scholars, they would firstly look at the matan to determine if it contradicts any elements of the syara' or logic, or if the matan appears in any other narrations. Thus, if there are problems with the matan, hadith scholars would reject the matan.

\section{Expressions that Portray the Laws of Hadith}

The conviction towards the authenticity of the sanad does not affect the authenticity of a hadith. It is clear that an authentic sanad does not make the authenticity of a hadith mandatory because matan criticism is still needed to evaluate the authenticity of the hadith. Hence, Ibn al-Qayyim (Furusiyyah: 245) had quoted, "It is known that the authenticity of the sanad is one of the conditions for an authentic hadith but it does not dictate the authenticity of a hadith". Ibn Hajar added that, "It is beyond doubt that a religious scholar would not replace the term "authentic" with the term "authentic sanad" unless it is substantiated by the matan" (As-Suyuti: Juz 1, 161).

Therefore, usually when the sanad is authentic, the matan of the hadith would also be authentic because in fact, within the sanad criticism there exist the matan criticism. Imam Syafie had said that, "When a thiqah narrator narrates from another thiqah narrator until it reaches the Prophet SAW, thus it is thabit (proved authentic)". However, the hadith's authenticity cannot be confirmed based on the sanad's authenticity because a thiqah is not perfect but only one who commits a few or extremely few mistakes.

Furthermore, if a narrator says, "all narrators are thiqah" or "the narrator is a narrator of an authentic scripture (Bukhari or Muslim)", it is actually of a lower standing than "the sanad is authentic". This is because the assumption "the sanad is authentic" means that all the aspects of the study on the sanad were completed and the conditions of an authentic sanad were adhered to. The claim that "the narrators were thiqah" only shows that the narrators were fair and dhobt but not necessarily followed the conditions for an authentic sanad. Ibn al-Jauzi also 
said, "There are hadith with sanads by narrators who were thiqah but the hadith was found to be false, contained untruthful elements and misleading".

\section{Criteria for a Hadith Critic}

Hadith scholars who are eligible to evaluate or criticize a hadith such as Imam Malik, Ahmad, al-Bukhari, Muslim and others are people who possess the qualifications and criteria to become critics of the sanad and matan of a hadith. According to Imam al-Zahabi, "There is no other way to mould a skilful and knowledgeable narrator other than to continuously learn and study the subject matter, have a lot of discussions, be focused, always be prudent and understand the subject matter, possess characteristics of piousness (taqwa) and religion, be impartial, have a good memory and always refer to scholars". According to Dr Faruq Hamadah (2008: 142), religious scholars are of the consensus that a narrator's critic should be someone of knowledge, pious, devout, truthful, humble and know the reasons why a narrator is accepted or rejected.

Dr Najm Khalaf (1989, p. 29) stressed that criteria for a matan critic is based on Imam al-Baihaqi, who quoted that: "The capability to differentiate between an authentic hadith or a weak one is not dependent on whether the narrator is fair or not but on how much of the hadith he has learned, socializing with experts on hadiths, constant referrals with these experts, reading the hadith and studying narrations by scholars on the hadith".

Ibn Qayyim al-Jauziyyah when asked about the possibility of identifying a false hadith based on the matan, said that the criteria for a matan critic is that one should be among the scholars of the hadith. He also said, "The one who can identify a false hadith that way would be an individual who is beaming with knowledge on authentic hadith, which has become a part of his flesh and blood. He has reached the level of an expert in the knowledge of hadith and the athar; the life of Prophet's SAW (sirah) and his teachings either in the form of his commands or prohibitions; what he has said, what he has preached, what he likes and dislikes and what he has bestowed on his followers, so much so that he feels he is with the Prophet SAW and his companions" (al-Jauziyyah, 1990)

Based on these statements by the scholars, the author has summarised that not anyone is capable of evaluating a hadith, either its sanad or its matan. Evaluation by an unqualified individual would render the evaluation void of quality from an academic perspective and eventually rejected. Hence, we find that Imam Muslim (1990, p. 218) had iterated for a long time, saying that, "The study on hadith and differentiating between an authentic and weak hadith is the work of experts on hadith because they safeguard the narrations and know about it compared to other people". It is not surprising that Imam al-Auza'ie would refer to a scholar in hadith initially before quoting a hadith although he is a famous faqih himself (al-Ramahurmuzi, 1404H: 318).

\section{The Relationship between the Results of Sanad and Matan Criticisms}

If we scrutinise the relationship between the results of the sanad and matan criticisms, we would find four situations, such as:

i. $\quad$ The sanad and matan are authentic

ii. $\quad$ The sanad and matan are weak

iii. The sanad is authentic but the matan is weak

iv. The sanad is weak but the matan is authentic

In these situations, only the first situation makes the hadith authentic. The law on hadith for the three remaining situations renders it weak and the situations are subsequently rejected. The first two situations are normal in a hadith whereby the sanad and matan are authentic and both the sanad and matan are weak. The third situation arises when there is some hidden flaw or contradiction in the matan. In the fourth situation, the matan is authentic because the contents of the matan are authentic. However, the narration is not authentic due to problems in the sanad.

\section{Conclusion}

Based on discussions, obviously there is a close relationship between sanad and matan criticisms when evaluating the hadith. Both these criticisms are essential when criticizing the hadith and in fact, the matan criticism is part of the sanad criticism. It would be incorrect to allege that hadith scholars are inclined or focus more on sanad criticisms when evaluating a hadith, when in fact the allegation portrays the fact that hadith scholars do not ignore matan criticisms when evaluating the hadith.

\section{References}

Al-A'zhomi, M. M. (1990). Manhaj al-Naqd 'Ind al-Muhaddisin Nasy'atuh wa Tarikhuh, Maktabah al-Kauthar, Saudi Arabia.

Al-Asqalani, A. al-F. A.bin H. al-A. (1986). Lisan al-Mizan. Dairah al-Maarif an-Nazhomiyyah, India. 
Al-Darimi, Abdullah bin Abdul Rahman Abu Muhammad Al-Darimi, Sunan al-Darimi. 1407H. (tahqiq Fawwaz Ahmad Zamarli \& Khalid al-Sab'u al-Ilmi) Dar al-Kitab al-Arabi, Beirut.

Al-Hakim, A. A. M. bin A. al-N. (1977). Makrifah Ulum al-Hadith. (tahqiq al-Sayyid Muazzam Husain) Dar al-Kutub al-Ilmiyyah, Beirut.

Al-Jawabi, M. T. (1986). Juhud al-Muhaddisin fi Naqd Matn al-Hadis al-Nabawi al-Syarif. Muassasah Abdil Karim bin Abdillah, Tunis

Al-Khair Abadi, M. A. L. (2005). Ulum al-Hadith Asiluha wa Muasiruha, Dar al-Syakir, Selangor, Malaysia.

Al-Khatib, Abu Bakar Ahmad bin Ali bin Thabit al-Khatib al-Baghdadi. (2013). al-Kifayah fi 'Ilmi al-Riwayah, Risalah Publisher, Beirut.

Al-Khatib, Abu Bakr Ahmad bin Ali bin Thabit Al-Khatib Al-Baghdadi. (2008). al-Jami' li Akhlaq al-Rawi wa Adab al-Sami'. (tahqiq Dr Muhammad Ra'fat Said) Dar Al-Wafa', Egypt.

Al-Muhammadi, Abdul Qadir Mustafa Abd al-Razzaq. (2005). al-Syaz wa al-Munkar wa Ziyadah al-Thiqat. Dar al-Kutub al-Ilmiyyah, Beirut.

Al-Nawawi, Abu Zakaria Yahya bin Syaraf. (1996). Syarh Sohih Muslim. (tahqiq Khalil Ma'mun Syiha), Dar al-Makrifah, Beirut.

Al-Qasimi, Muhammad Jalal al-Din. (2010). Qawaid al-Tahdith. Dar al-Nafais, Beirut.

Al-Ramahurmuzi. al-Hasan bin Abdul Rahman. 1404H. al-Muhaddis al-Fasil Bain al-Rawi wa al-Waie. (tahqiq Muhammad Ujjaj Al-Khatib) Dar Aal-Fikr, Beirut.

Al-Suyuti, Jalal al-Din Abd al-Rahman bin Abi Bakr. (2005). Tadrib al-Rawi. (tahqiq Abd al-Wahhab Abd al-Latif), Dar al-Turath, Cairo.

Al-Syafie, Muhammad bin Idris. (2009). al-Risalah, Dar al-Kutub al-Ilmiyyah, Beirut.

Al-Zahabi, Muhammad bin Ahmad bin Uthman. (1998). Tazkirah al-Huffaz. (tahqiq Zakaria Umairat). Dar al-Kutub al-Ilmiyyah, Beirut.

Al-Zarkali, Khair al-Din. (1980). al-A'lam Qamus Tarajum li Asyhur al-Rijal wa al-Nisa'. Dar al-Ilmi li al-Malayin, Beirut.

Al-Zarkasyi, Badr al-Din Muhammad bin Abdullah. (2000). al-Ijabah fi Ma Istadrakathu Aisyah 'ala al-Sohabah. al-Maktab al-Islami, Beirut.

Falatah. Umar bin Hasan. (1981). al-Wadh'u fi al-Hadith. Maktabah al-Ghazali, Dimascus.

Ibn Adi, Abu Muhammad Abdullah bin Adi al-Jurjani. (1998). al-Kamil fi Dhuafa' al-Rijal. (tahqiq Dr Suhail Zakkar). Dar al-Fikr, Beirut.

Ibn al-Jauzi, Abu al-Farji Abdul Rahman bin Ali. (1995). al-Maudhuat. Dar al-Kutub al-Ilmiyyah, Beirut.

Ibn al-Solah, Abu Amrin Usman bin Abd al-Rahman al-Syaharzuri. (2001). Muqaddimah Ibn al-Solah. (tahqiq Dr Abdul Hamid Handawi) al-Maktabah al-Asriyyah, Beirut.

Ibn Qayyim al-Jauziyyah, Muhammad bin Abi Bakr al-Zuraie. (1990). Naqd al-Manqul wa al-Mihak al-Mumayyaz Baina al-Mardud wa al-Maqbul. Dar al-Qadiri, Beirut.

Ibn Qayyim al-Jauziyyah, Muhammad bin Abi Bakr al-Zuraie. (1993). al-Furusiyyah. (tahqiq Masyhur bin Hasan). Dar al-Andalus, Saudi Arabia.

Muslim, Abu Al-Husain Muslim bin al-Hajjaj al-Qusyairi al-Naisaburi. (1990). al-Tamyiz. Maktabah al-Kauthar, Saudi Arabia.

Muslim, Abu al-Husain Muslim bin al-Hajjaj al-Qusyairi al-Naisaburi. (2012). Sohih Muslim. Risalah Publisher, Dimascus.

Najm Abdul Rahman Khalaf. (1989). Naqd al-Matn Baina Sina'ah al-Muhaddithin wa Mato'in al-Mustasyriqin. Maktabah al-Rusyd, Saudi Arabia.

\section{Copyrights}

Copyright for this article is retained by the author(s), with first publication rights granted to the journal.

This is an open-access article distributed under the terms and conditions of the Creative Commons Attribution license (http://creativecommons.org/licenses/by/3.0/). 